\title{
TWO CASES OF CYTOMEGALIC INCLUSION ENCEPHALITIS
}

\author{
BY \\ A. M. G. CAMPBELL, JOAN GUY and W. GREY WALTER \\ From the Department of Child Health, Bristol University
}

(RECEIVED FOR PUBLICATION JUNE 27, 1952)

In 1934 Dawson described a new type of encephalitis with a distinctive clinical and pathological picture which has been recognized periodically during the last few years and has been well reviewed by Greenfield (1950) and other authors.

This disease is usually found in children and in most cases pursues an unrelenting course of weeks or months to death. It is impossible to conjecture as to whether any patients ever recover.

The disease always begins with mental symptoms and in the majority of cases there are severe myoclonic spasms. A feature of the disease is the normal cerebrospinal fluid apart from the high incidence of a paretic Lange reaction. The pathological picture is characteristic and in many cases acidophilic inclusion bodies have been found in the nerve cells of the brain.

We propose to describe two cases in children, not because they show many new factors but because we feel that paediatricians may still be unaware of the disease, which is probably somewhat commoner than is imagined, and because a summary of its clinical and pathological features brings out a fairly constant clinical picture which makes diagnosis during life a possibility.

\section{Case Reports}

Case 1.-B.W., aged 11 years, was admitted to hospital on May 9, 1951. She was the elder of two children, her brother, aged 7 , being asthmatic. Both parents are alive and well, though her mother suffers from rheumatoid arthritis.

In July, 1950, she had a severe insect bite on the leg, which became septic and necessitated out-patient treatment.

From August, 1950, onwards her parents noticed a change in her temperament and in her facial expression. She became listless and apathetic, and, always backward at school, her progress deteriorated. In December, 1950, she had a vague febrile illness lasting three weeks, characterized by headache, aching limbs and nasal catarrh. Afterwards she continued to complain of occasional headaches.

On March 16, 1951, she was knocked down by a bicycle. She sustained a cut on the forehead and was dazed, but did not lose consciousness. Though she vomited once after the accident she appeared to recover completely. Two weeks later her mother noticed that she seemed to be in a 'dreamy state'. Later that day she fell down several times for no apparent reason. There was nothing to suggest that she had either fainted or had a fit.

From that time onwards she continued to stumble and fall. Her movements became clumsy and jerky and she had difficulty in dressing herself. Personality changes persisted; she developed a facile smile, became reluctant to talk and answered questions slowly. When sent on an errand, she returned having purchased nothing and holding a 10s. note in the air. Her headaches became more frequent and she had a tendency to vomit.

On examination she was seen to be a tall, thin girl with a vague, dreamy expression. Reluctant to speak spontaneously, she was cooperative and answered questions sensibly, though her speech was slightly jerky. She made occasional fidgety movements. There was some facial asymmetry, the right side of the face moving less than the left.

Her gait was unsteady and she showed some muscular hypotonicity and incoordination. Romberg's sign was negative. The right knee jerk was brisker than the left. The ankle jerks were not obtained. The plantar responses were flexor. Sensation was difficult to assess as the patient answered slowly and did not always appear to understand. The pupils, which were crescentic, reacted to light. The ocular fundi were normal apart from a suggestion of pallor of the left disc. Examination of other systems showed no abnormality.

An investigation for toxoplasmosis was negative.

The Mantoux test $(1: 100)$ was negative, as also were the Wassermann and Kahn reactions.

Radiographs of the skull, sinuses and chest were normal.

The erythrocyte sedimentation rate was $7 \mathrm{~mm}$. in one 
hour. A blood count gave $\mathrm{Hb} ., 100 \%$; leucocytes, 4,300 (polymorphs $75 \%$, lymphocytes $24 \%$, monocytes $1 \%)$.

Examination of the cerebrospinal fluid showed a pressure of $300 \mathrm{~mm}$., and a clear, colourless fluid with one white cell per c.mm., and $15 \mathrm{mg}$. protein per 100 $\mathrm{ml}$. Globulin was not increased. The Lange curve was normal.

ELECTRO-ENCEPHALOGRAPHY.-Records were taken on April 17 and 19, 1951. A six-channel apparatus was used with an automatic wave analyser. The electrode placements and instrument settings were as indicated in Fig. 1A and B. The results were the same on both occasions. deep in to the head from the temporal region on both sides, was responsible for the sharp wave; the other, antero-posteriorly oriented, gave rise to the slow wave, which had a duration of 1.25 seconds.

Electromyograms showed that the muscle groups involved in the jerking were mainly the extensors of the left arm and right leg but all groups participated from time to time. The cerebral discharges were so constant in their wave-forms that when superimposed there was complete identitỳ even to minute details in their pattern (Fig. $2 \mathrm{~A}$ and $\mathrm{B}$ ).

The repetition rate of the cerebral discharge was also unusually regular, varying from six to 20 seconds.

Such unvarying regularity is perhaps the most com-

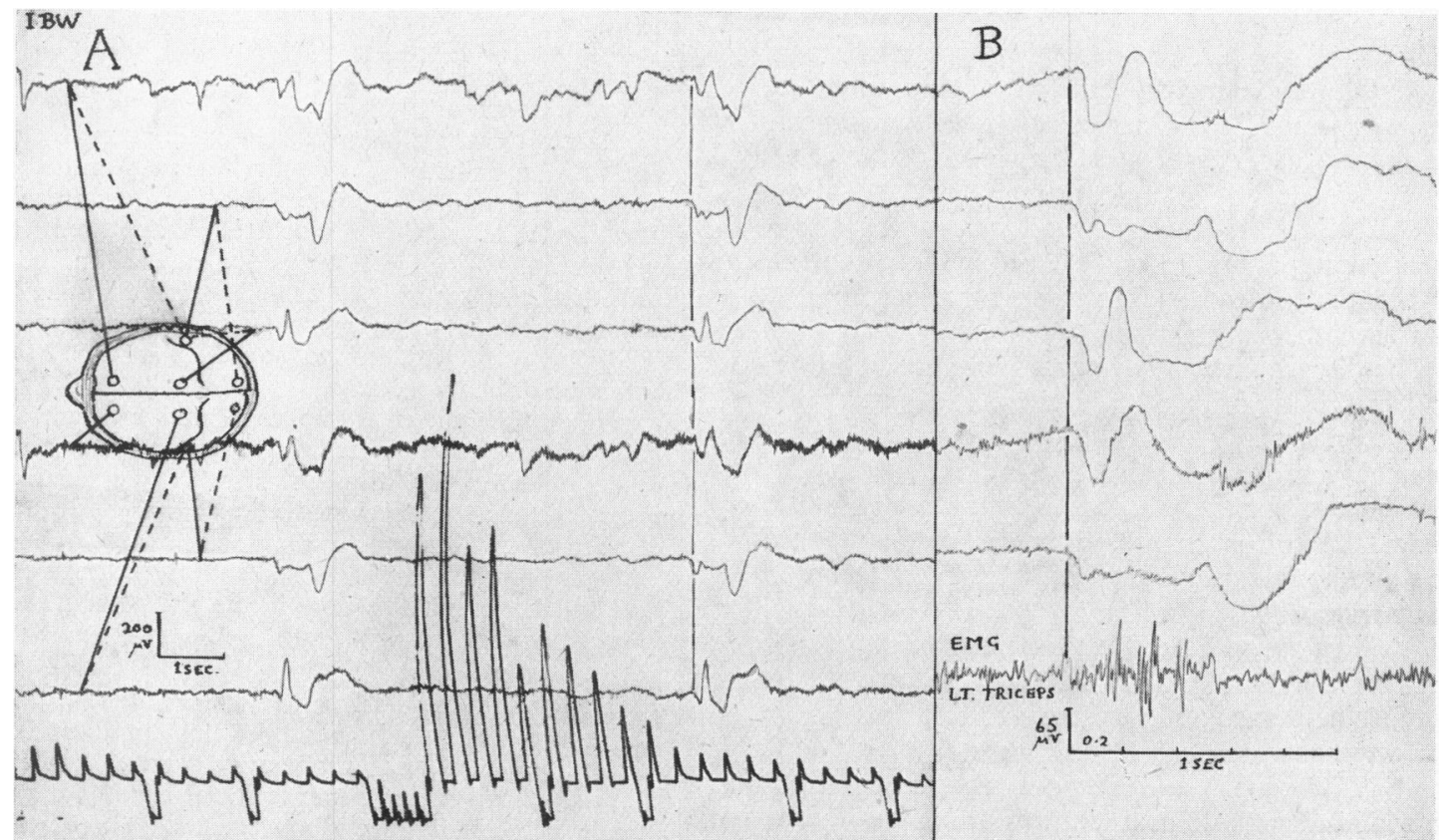

FIG. 1.-A. E.E.G. taken at low speed and reduced amplification showing two of the complexes. The differing wave-forms in the various channels indicate a complex generator and the symmetry of the two hemispheres a subcortical origin. B. At higher speed and amplification the wave-form is displayed more clearly and the time relation to the muscular spasm can be observed.

In the occipital regions there were moderate-sized alpha rhythms at $7-8 \mathrm{c} / \mathrm{s}$. attenuated by visual activity and somewhat larger on the right side; far more prominent than these normal rhythms were very large $(200$ microvolt) intermittent sharp-and-long wave discharges which appeared at intervals of six to 20 seconds, and were accompanied by myoclonic spasms of the limbs (Fig. 1).

The discharges were most evident in the temporal regions of both hemispheres and special studies were made to work out the geometry of the equivalent generators responsible for these cerebral discharges, and the peripheral distribution of the muscular activity. The cerebral discharges were found to emanate from two generators. One, transversely oriented and extending pletely pathological character encountered in the study of cerebral activity; it is not in any sense diagnostic of any particular disease state and is found in varying degrees in all types of epilepsy, particularly when there are signs or symptoms of disturbance in the subcortical nuclei.

Extreme regularity of electrical discharge and uniformity of pattern are not found in conditions where only the cortex is affected by disease; nor, of course, are these features characteristic of infancy or of deep sleep, when the more irregular slow rhythms are as common as they are in relation to cortical pathology.

Study of the time relations between the cerebral and muscular discharges showed that during a jerk-discharge the synchronous electromyograms always began during 
the first electro-negative phase in the temporal lobes, and reached their maximum during the following positivity.

Progress. Myoclonic spasms began in April, 1951, first involving mainly the legs and later the right arm and left leg. She developed slight facial weakness on the right side.

About May 20, 1951, her speech became slurred, and she became incontinent of urine and faeces. She lay with the limbs permanently flexed, and activity was hampered by the frequent myoclonic spasms. Treatment with artane, $2 \mathrm{mg}$. daily, was without effect on the myoclonic spasms, which became more frequent and more violent and were accompanied by oculogyric crises. air sinuses, pituitary fossa and middle ears.

A $5 \mathrm{~cm}$. cube of brain tissue was removed from the right parieto-occipital region with sterile precautions and sent to Dr. Weston Hurst for investigation for virus.

A full necropsy was performed 24 hours later by Dr. A. D. Fraser, who found that death had been due to acute bronchopneumonia, associated with marked toxic changes in myocardium, liver, spleen and kidneys.

As a result of his investigations, Dr. Weston Hurst reported that 'wholly negative' results were obtained on animal inoculation.

Pathological Report (Dr. M. C. W. Dodgson). Except for some increased prominence of the cerebral subcortical vessels, no macroscopical changes were noted

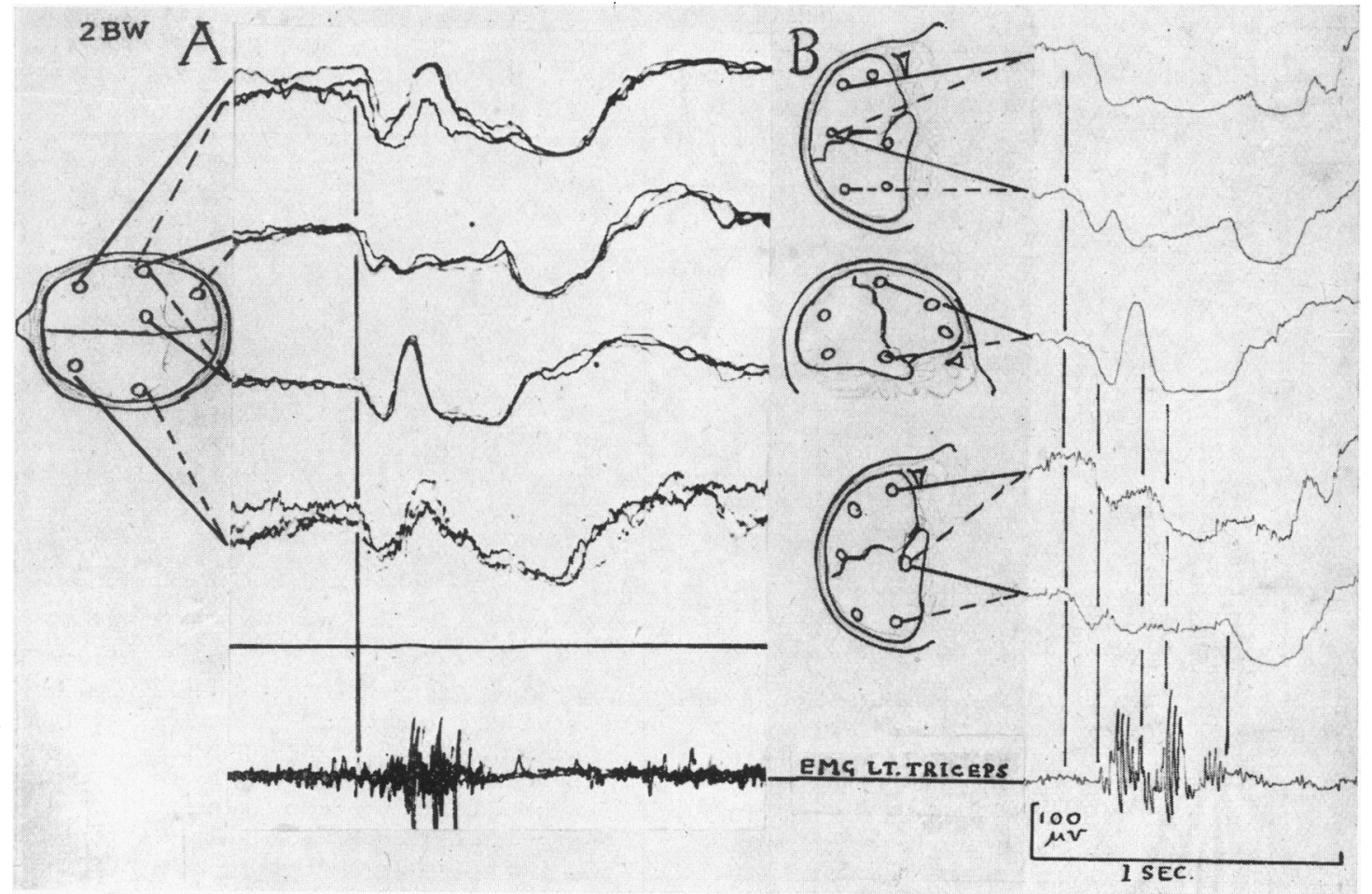

Fig. 2.-A. Print from three records at the cerebral discharge superimposed to demonstrate the unusual constancy of its wave-form and the constant grouping of the muscle discharge. B. The distribution of the various components in the right hemisphere and their relation to muscle discharge.

Towards the middle of June, 1951, the spasms were distinctly less intense but her condition began to deteriorate. She grew progressively more emaciated and latterly developed bilateral facial paralysis and bilateral ptosis.

On July 7, 1951, she was comatose and she died on July 19, 1951.

NECROPSY. The brain was removed two hours after death by Professor T. F. Hewer. Apart from a localized, pale grey exudate over the vertex, more on the left side than on the right, alongside the great veins, no changes were detected in the skull, meninges, brain, venous and externally or on sectioning the brain.

Blocks were taken from frontal cortex and from the pons for paraffin embedding; for frozen sections from the main cortical areas, the thalamus and the pons, and for celloidin embedding from all areas.

'In addition to the usual staining methods, Lendrum's phloxine tartrazine stain for inclusion bodies was used on the paraffin and celloidin sections.

Widespread histological lesions were encountered throughout the grey matter, where many of the larger nerve cells, picked out apparently at random, exhibited severe changes and were surrounded by glial cells. 
In the cerebral cortex occasional pyramidal cells in the third, fifth and sixth layers displayed shrinkage and chromatophilia of the cytoplasm, although formed Nissl substance was absent; even, dark staining of the nucleus, which no longer possessed a chromatin framework; and swelling, blurring of outline and loss of refractility of the nucleolus. The nuclei of a small proportion of these damaged cells were shown to contain small vacuole-like, faintly phloxinophilic inclusions in preparations stained by Lendrum's method.

The surrounding interstitial cells were predominantly microglial, although small round cells and occasional plasma cells were also seen (Fig. 3). Similar glial nodules also surrounded capillaries, in which no central nerve cells were visible. A single typical example of this type of lesion was found in the posterior columns of the cervical cord. There were occasional perivascular cellular infiltrations in the cortex, and many of the

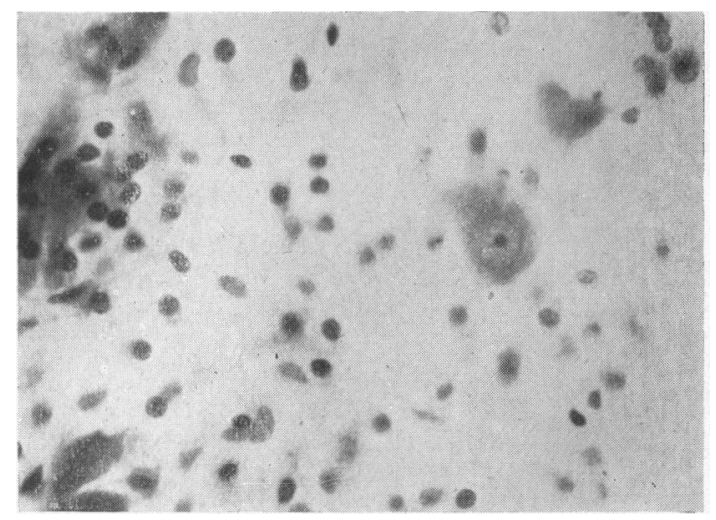

Fig. 3.-Accumulation of glial and other interstitial cells surrounding damaged nerve cells in dentate nucleus. Nissl $\times 400$.

capillary walls, especially in the neighbourhood of glial nodules, were more than usually cellular, as a result either of endothelial cell or microglial proliferation.

Only slight differences were detected in the degree of involvement of the various parts of the cortex; of all sites, the occipital region appeared to be the least heavily implicated and the temporal cortex the greatest. The larger cells in the pyriform cortex, and particularly the pyramidal cell layer of the cornu ammonis, exhibited examples of the change described above. None of the Betz cells were involved in the severe cell change or showed inclusions, although they were all in a state of chromatolysis.

Although practically every subcortical centre of grey matter was to some extent involved, the severest changes were seen in the dorsal part of the thalamus, not anatomically confined to any particular nucleus, and in the nuclei pontis. In both these situations there was a generalized astrocytic and microglial gliosis of grey matter and perivascular collections of round cells (Fig. 4).

No changes were noted in the caudate nucleus and putamen, although a few damaged nerve cells surrounded by glial clusters were seen in the globus pallidus and subthalamic nucleus. The hypothalamic region and mamillary bodies, as well as the red nucleus, periaqueductal grey matter, oculomotor and rectal nuclei, were only lightly involved. The amygdaloid complex and the substantia nigra, on the other hand, showed rather more frequent examples of severe nerve cell damage, although the latter was not nearly so badly affected as the nuclei pontis.

The reticular substance and the cranial nerve nuclei of the pons and medulla, particularly the facial, showed occasional damaged cells. In the inferior olivary nucleus there was a uniform shrinkage and increased cytoplasmic chromatophilia of the nerve cells, although only a few were surrounded by glial clusters. On the other hand, the dentate nucleus, whose cells were not in this pyknotic state, showed more frequent examples of severe nerve cell change. Elsewhere in the cerebellum there were no departures from normality, the Purkinje

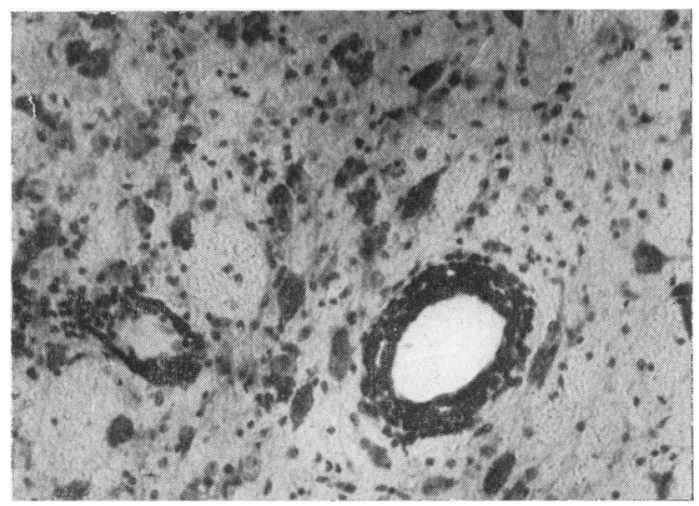

FIG. 4.-The same as Fig. 3, but in addition showing a mesodermal reaction in the nuclei pontis. Nissl $\times 100$.

cells, molecular and granular layers, and central white matter exhibiting no changes. The anterior horn cells in the cervical cord appeared shrunken and contained unusually compact Nissl substance, although no examples of severe nerve cell change were observed.

There was an obvious increase in the density of glial cell nuclei in the white matter immediately below the cortex of all regions in the cerebral hemispheres, accompanied by an increased cellularity of vessel walls, although there were no perviascular infiltrations.

In Holzer preparations it was possible to demonstrate a fine glial fibrosis, which did not, however, extend into the depths of the centrum ovale, but was confined approximately to the U-fibre zone. No evidence of myelin breakdown could be detected. Apart from these relatively insignificant changes, no other alterations in white matter were encountered, either in the cerebrum or at lower levels.

Case 2. M.G., a previously healthy child aged 6 years, was admitted to hospital on June 15, 1951. There was a history of two convulsions at the age of 2 years, associated with teething. She was the youngest of seven children and they and both parents were all alive 
and well. There was no history of contact with infection of any kind before the onset of the illness.

The first symptoms began 12 to 15 months before admission, with attacks of coarse tremor occurring at night just as she was falling asleep. During the attack the child would cry out and stare vacantly, but did not appear to lose consciousness. The attacks recurred for two or three consecutive nights every two or three months. There had been one of these attacks 10 days before admission.

Four days before admission the child fell downstairs, without apparent injury, but since the fall there had been continued jerking movements and marked intention tremor affecting mainly the left arm. There had been ataxia with a tendency to fall backwards. Speech was normal, but the child was talking continually and at times did not appear to recognize people. At night she was noisy and had hallucinations.

She had attended school up to the day of admission to hospital, but study of the school books showed steady deterioration for several weeks.

For the past week there had been some incontinence of urine by day and night, and the mother had noticed behaviour changes; the child had become spiteful and a bad mixer. Previously she had always dressed herself, but for the past few days she had been unable to do so. The night before admission she complained of frontal headache. There had been no vomiting.

On examination the temperature was $98^{\circ} \mathrm{F}$., the pulse $80 / \mathrm{min}$. and respirations $24 / \mathrm{min}$.

She was a thin child with somewhat immobile facies. She was irritable and uncooperative and reluctant to talk, though speech was normal but toneless. Her behaviour was rational and there was no impairment of vision or hearing. There was slight ataxia on walking and she showed a tendency to fall backwards. She was unable to sit for long without support. Power in the limbs was normal and equal on both sides.

There was a fine tremor of the left arm, accentuated by voluntary movements into clonic spasms.

The cranial nerves were normal. The pupils reacted to light and to accommodation and there was nystagmus to the right. The fundi were normal. Tendon reflexes were present, but brisk. There was no neck rigidity and Kernig's sign was negative. Sensation was normal.

Lumbar puncture gave a pressure of $300+\mathrm{mm}$., and the fluid was clear and colourless with 3 cells per c. mm., chlorides $730 \mathrm{mg}$. $/ 100 \mathrm{ml}$., protein $60 \mathrm{mg}$./100 ml., a slight increase in globulin and $79 \mathrm{mg}$. sugar per $100 \mathrm{ml}$. The fluid was sterile on culture. The Lange curve was 555432000.

The Wassermann reaction was negative.

There were 17,000 leucocytes per c.mm. of blood (polymorphs $65 \%$, lymphocytes $32 \%$, monocytes $3 \%$ ).

A radiograph of the skull was normal.

EleCtro-EnCEPHALOGRAPHY. Records were taken on June 16, 1951, using the same methods as for Case 1. The principal feature was a large $(500$ microvolt $)$ delta rhythm in both occipital lobes. This extended into the temporal region on the left side. The analysis was complex and variable; the most regular peaks were at
2 and $3 \mathrm{c} / \mathrm{s}$ and there was also a theta component at $6 \mathrm{c} / \mathrm{s}$ which was augmented by closing the eyes. In the temporal region there was a small persistent component at $14 \mathrm{c} / \mathrm{s}$. The delta activity was augmented on the right side by closing the eyes, but with the eyes open tended to focus in the left occipital region. The alpha rhythms were small and intermittent with frequencies from 7 to $8 \mathrm{c} / \mathrm{s}$. The patient was alternately agitated and somnolent; while sleeping a very large ' $K$ complex' could be evoked by a sudden sound. Photic stimulation had no unusual effects.

The complex analysis of the slow activity suggested that it was associated with a cortical disturbance, but the rhythm of the slower components, their responsiveness to stimulation and their correlation with somnolence suggested a deeper disturbance also. The greater responsiveness of the delta activity on the right side suggested that the subcortical anomaly might be mainly in the brain stem and structures around the third ventricle associated with the right occipito-parietal region. Conversely the persistence of the more irregular slow rhythms on the left side suggested the presence of a cortical disturbance in the left occipital lobe (Figs. 5 and 6).

Progress. Deterioration was rapid. For the first few days she was reluctant to speak, but understood and responded to requests. At night she was noisy with visual and auditory hallucinations. She became gradually more drowsy and developed typical Parkinsonian facies and rigidity. She was unable to sit without support and movements were slow and the tremor increased in intensity. After a week she began to have constant coarse jerking spasms of the left arm and leg and there was marked neck rigidity. This progressed until the child was lying in gross opisthotonus with continual torsion spasms of the left side of the body and oculogyric crises. She remained afebrile and lucid with full comprehension, but executive ability was greatly hampered by spasms and rigidity. She took fluid and diet well and had no difficulty in swallowing till a few days before death.

Treatment with artane, $2 \mathrm{mg}$. daily, had no effect on the rigidity, and heavy sedation with soluble phenobarbitone, gr. 1 four-hourly, was necessary to conțrol the spasms and to prevent the child injuring herself.

Four days before death the opisthotonus decreased and she became comatose, but was still able to recognize her parents and to take fluids. She developed multiple bedsores, some of which became infected, and ran an irregular fever up to $.103^{\circ} \mathrm{F}$. She developed a fine generalized erythematous eruption, thought to be a sweat rash.

Terminal respiratory infection occurred and she died in hyperpyrexia $\left(106^{\circ} \mathrm{F}\right.$.) 'on July $12,1951$.

NeCropsy. A necropsy was performed by Dr. N. J. Brown 19 hours after death. The principle pathological changes were acute bronchopneumonia, accompanied by a dry pleurisy on the right side and by patchy areas of basal collapse in both lungs. There was a slight excess of clear fluid in the pericardium. The brain weighed $1,170 \mathrm{~g}$. There was some flattening of cerebral 


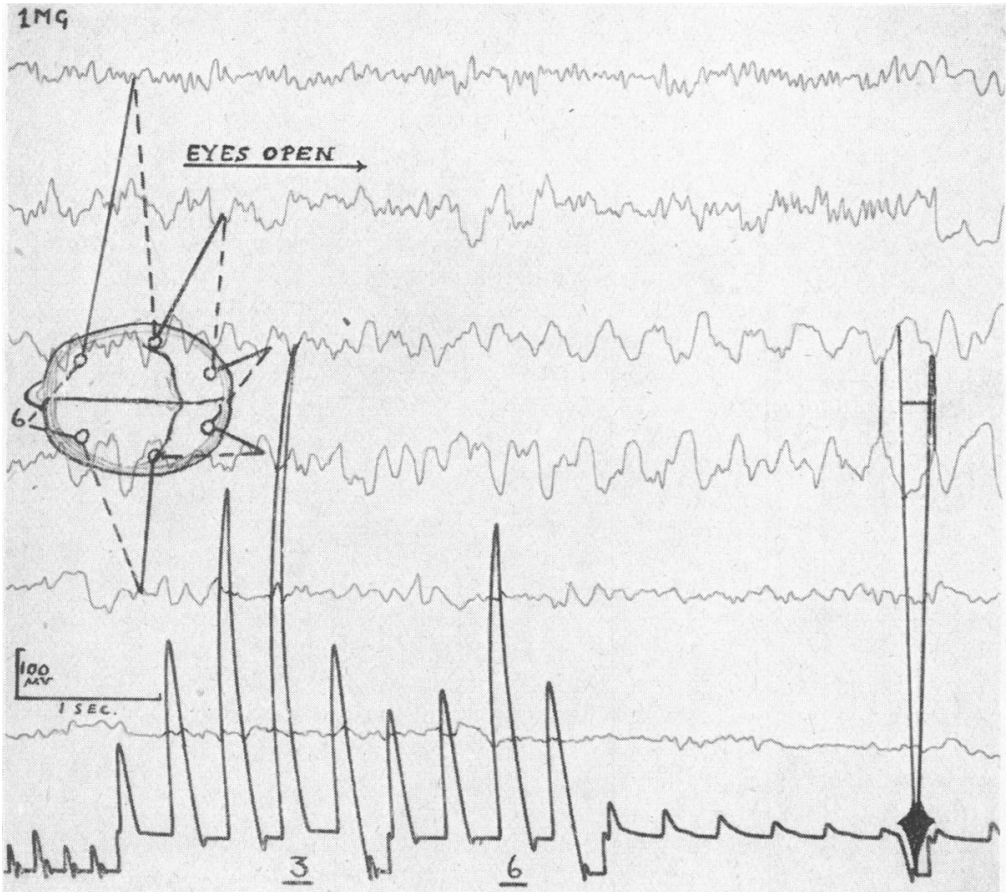

FIG. 5.-E.E.G. taken during an alert phase showing the left occipital delta rhythm with components at 3 and $6 \mathrm{c} / \mathrm{s}$ and the faster rhythms at 14 and $18 \mathrm{c} / \mathrm{s}$ from the opposite side. The analysis is of those components which were out of phase in channels 3 and 4 . the other areas examined the myelin appeared normal. The optic nerves, chiasma and anterior parts of the optic tracts also were normal, as were the optic radiations.

In paraffin sections the medulla and cerebellum showed little abnormality. There was perhaps slight microglial excess in the inferior olives but no glial stars were seen here. In the pons the nuclei pontis showed more definite microglial excess and some degenerative changes in nerve cells but no glial stars, perivascular infiltration or inclusion bodies.

The midbrain seemed entirely normal. In view of the terminal Parkinsonian attitude .special attention was paid to the substantia nigra, but nothing abnormal was seen in its cells. In the external geniculate body there was a slight excess of microglia, almost amounting to glial stars in places. No perivascular infiltration was seen here. Some nerve cells were shrunken and their nucleus was pushed to the side but none containing inclusion bodies were seen.

convolutions and obliteration of sulci, and there was a pressure cone in the foramen magnum.

As in Case 1 a cube weighing approximately $50 \mathrm{~g}$. was removed from the right cerebral hemisphere with sterile precautions and sent to Dr. Weston Hurst for virus investigation. The results in this case also were wholly negative.

Pathological Report (Dr. J. G. Greenfield). The brain stem had been divided in the mid-sagittal plane and the hemispheres separated along the line of the corpus callosum and the third ventricle.

There was no definite sign of disease on naked eye examination.

Pieces from various areas were embedded in paraffin after 10 days' mordanting in saturated $\mathrm{Hg} \mathrm{Cl}_{2}$ at Professor Lendrum's suggestion, and stained by Lendrum's phloxine tartrazine method, as well as by haematoxylin, van Gieson stain and phosphotungstic acid haematoxylin (Mallory). Frozen sections were also made from the parieto-occipital region and fronto-parietal vertical region of the brain and stained by Scharlach $R$ and haemalum. The latter showed an area of partial sudanophilic myelin degeneration in the white matter under the parieto-occipital fissure in the form of loosely packed fine spicules and granules of lipid, most of which were anisotropic. They were mostly intracellular but some still remained free, lying among myelin sheaths which were sparser and more beaded than normal. In
The optic thalamus showed a similar appearance, general slight excess of microglia and occasional degenerated neurons, and here an occasional vessel ringed with lymphocytes. No abnormality was seen in the corpus striatum including the globus pallidus.

Very little abnormality was seen in the pre-frontal, pre- and post-central, hippocampal and inferior temporal and fronto-mesial areas of cortex. An occasional vessel had plasma cells and lymphocytes in its wall, rather more commonly in the subcortical white matter than in the cortex, and a patchy excess of microglia and a few paired astrocyte nuclei were seen in the cortex. In all these areas, apart from an occasional infiltrated vessel, the changes were so slight that it would have been almost impossible to make a diagnosis of encephalitis and certainly impossible to decide its type 'from the histological appearances.

In sections near the parieto-occipital fissure and through the occipital lobe and the posterior horn of the lateral ventricle much more definite inflammatory changes were found, many nerve cells containing typical intranuclear and intra-cytoplasmic inclusions. The inflammatory reactions in the cortex included considerable microglial excess with formation of glial nodules, multiplication of astrocyte nuclei, which showed pairs and fours; in some places there was also swelling of the cell body, but no formation of neuroglial fibres was seen (Figs. 7, 8 and 9). 


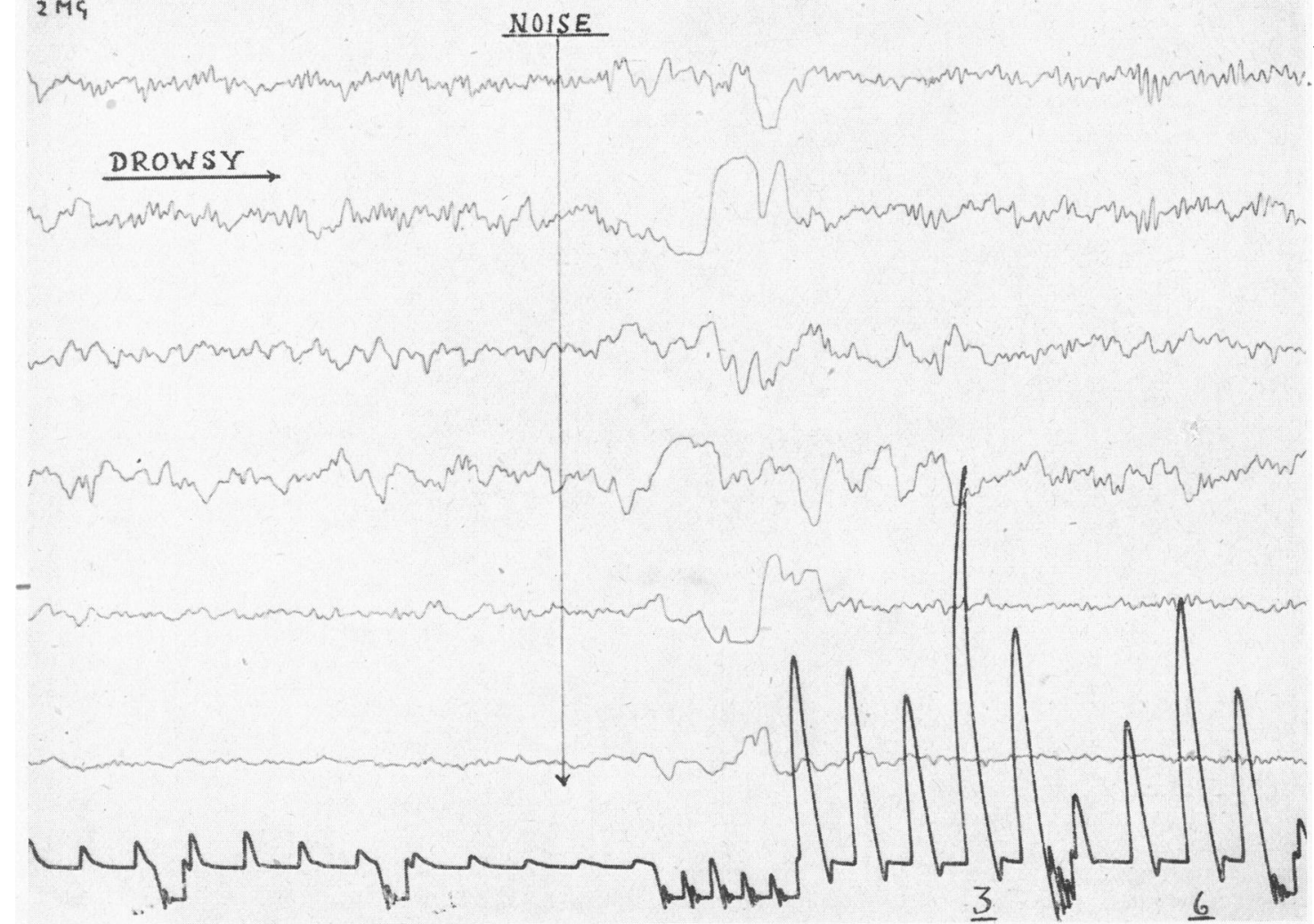

FIG. 6.-E.E.G. taken during drowsy state showing the widespread slow complex evoked by a sound stimulus superimposed on the slow and fast activity. The distribution of the evoked response is not the same as that of the persistent discharges. Electrodes, gain. and time scale as in Fig. 5.

Round many vessels there was a single layer of plasma cells and a few plasma cells were seen loose in the tissues.

The nerve cells, especially the pyramidal cells of the third, fifth and sixth layers, were, in the most damaged areas, so degenerated that they were difficult to distinguish. In several places, but not always in the most severely inflamed areas, neurons containing inclusions, both intranuclear and cytoplasmic, were so numerous that at least one could be seen in almost every oil immersion field. The inclusions were very typical; those in the nucleus varied from small bodies, one-third of the diameter of the nucleus, to bodies which filled the nucleus entirely leaving only a zone of chromatin granules round them; the smaller bodies were surrounded by a clear halo. All were hyaline and nongranular. The cytoplasmic inclusions varied from small, rounded or oval, brilliantly phloxinophil bodies, to crescentic masses usually staining orange with Lendrum's method lying beside the nucleus and representing the only visible cytoplasm. All grades between these extremes were seen.

Usually cells with such flocculent cytoplasmic inclusions showed a fairly large nuclear inclusion also,

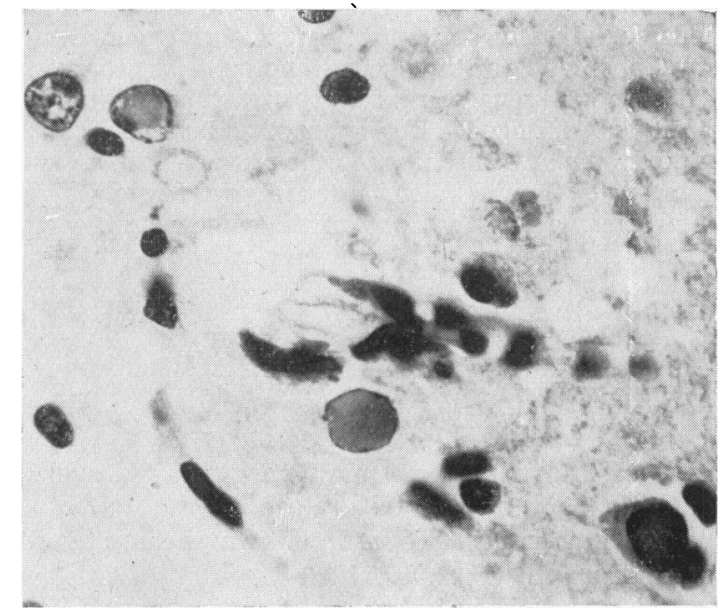

FIG. 7.-Occipital cortex: three nerve cells are seen with intranuclear inclusions. In that to the left a clear halo is seen between the inclusion body and the nuclear membrane. In the nucleus to the right the intranuclear body which fills the nucleus stains more deeply with phloxine than in the other two cells. Lendrum's phloxine-tartrazine stain $\times 650$. 


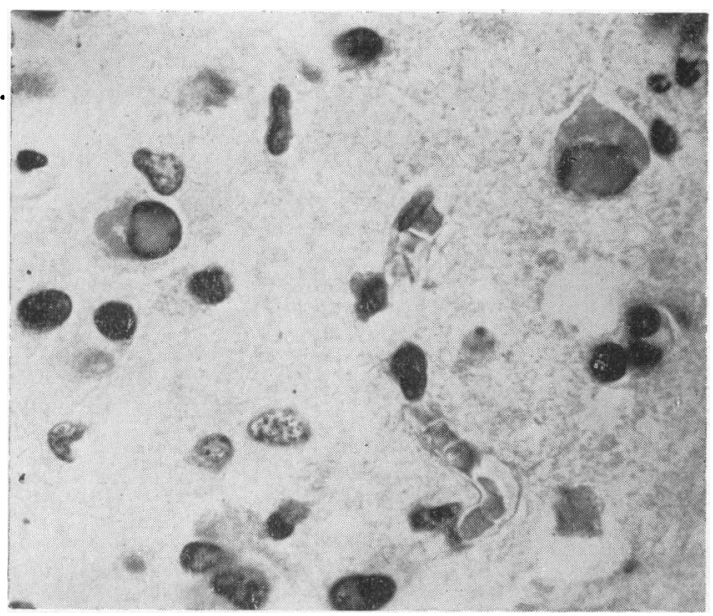

FIG. 8.-Occipital cortex: two nerve cells are seen in a state of severe degeneration with both nuclear and cytoplasmic inclusion bodies. The latter appear as flocculent, pale-staining material. Lendrum's phloxine-tartrazine stain. $\times 650$.

but the size of the latter bore little relationship to the degree of cytoplasmic degeneration, except that cytoplasmic degeneration always accompanied an inclusion which filled the nucleus entirely.

In areas showing many such inclusion bodies an occasional cell could be seen with a rounded nucleus, rather larger and less chromophilic than that of a plasma cell, and with a large cell body filled with phloxinophilic granules from 1 to $2 \mu$ in diameter. These cells were too sparse for their nature to be studied further. They were not recognized in sections stained by other methods.

In the occipital white matter underlying the more inflamed areas of cortex there was considerable loss of myelin, swelling of the nucleus and cytoplasm of astrocytes with fibrous gliosis and perivascular infiltration. Many of the oligodendrocytes had a clear, more or less phloxinophilic, central area in their nuclei, and a few of these cells showed a small tag of cytoplasm. These clear areas appeared to be of the same nature as the intranuclear inclusions in the nerve cells (Figs. 7, 8 and 9).

\section{Discussion}

Clinical and Pathological Findings. The principal findings in many of the cases hitherto recorded are summarized in Table 1.

It is remarkable how many cases have shown as an early symptom a deterioration in school or other work which is well shown by drawings done by our second patient (Figs. 10 and 11).

It is also striking how many patients have been found wandering in an apathetic state, and their poverty of speech is extremely striking. The facial appearance alters in these children, and this is shown by the photographs of Case 1 which show a lack of

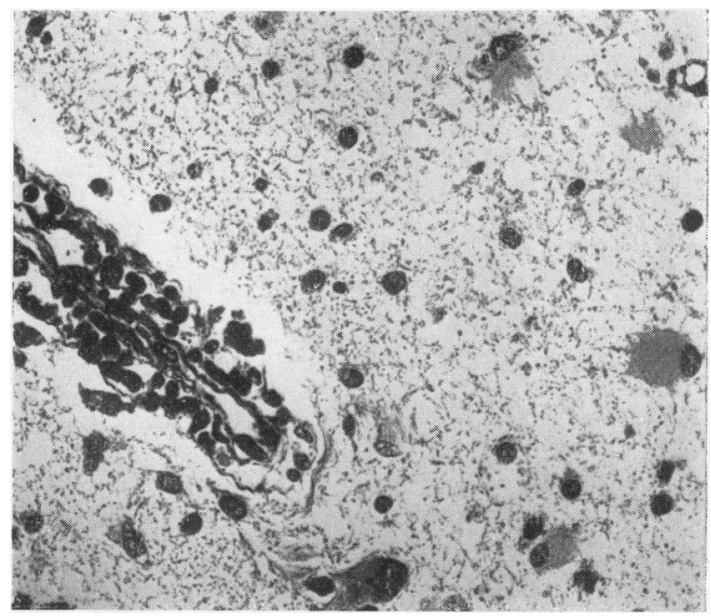

FIG. 9.-Occipital subcortical white matter showing lymphocytic infiltration of the wall of a small vessel and swelling of astrocytes. Iron haematoxylin and van Gieson stains. $\times 350$.

emotional expression and a somewhat plastic smile (Figs. 12 and 13).

We feel that this disease is probably a new entity and that the older neurologists could not have missed such a clinical picture. Its aetiology is entirely unknown, but it has been presumed, because of the finding of inclusion bodies, that it may be due to an unknown virus. Every attempt was made in our cases to discover an aetiological factor. The first child had had an insect bite of some severity about a year before death, but we have no evidence that the disease could be dye to this and animal inoculation has been disappointing. There is no evidence that one disease is related to the herpes simplex virus, which is known to produce an encephalitis with inclusion bodies, and although material from both our cases reached Dr. Weston Hurst, he was unable to deduce anything from animal inoculation. This has been the experience of other workers.

The differential diagnosis is mainly from chorea, and the death of one patient who died recently in Wales, was thought, until death, to be due to a severe form of chorea. The electro-encephalographic changes eventually shown in most cases are, of course, entirely different from those of chorea.

Many cases have been admitted to neurosurgical units with the mistaken diagnosis of a tumour or of a subdural haematoma, and careful clinical investigations usually rule out a space-occupying lesion. Generalized neurosyphilis produced a very similar clinical picture to these sub-acute 


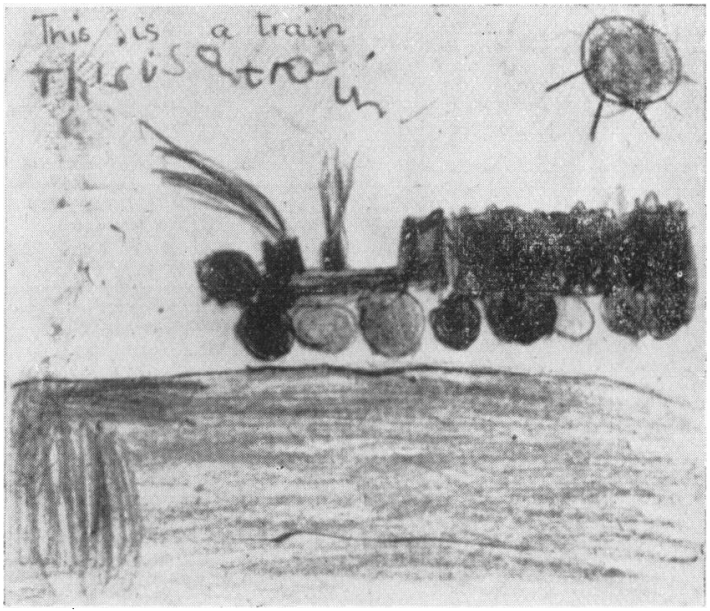

FIG. 10.-Normal drawing of train for her age done early in April, 1951.

encephalitides in a case recently under the care of Dr. Spillane.

Our second case is of particular interest on account of the very localized incidence of inflammatory and degenerative changes and the relative absence of damage to the pontine nuclei, which most cases seen by Dr. Greenfield have previously shown. This local characteristic of the lesion may be associated with the short duration of the clinical symptoms, and the localization of the lesion to the occipital lobe, shown pathologically and by the electroencephalograms, may have some bearing on the clinical symptom of visual hallucinations with which this child presented.

It is thought that the nocturnal attacks, which came on occasionally during the 12 months before coming to hospital, were epileptic attacks and not necessarily associated with the disease, although one or two cases recorded in the literature have had a long history of epilepsy before the development of the encephalitis.

In the first case the duration of the illness was of average length, six to nine months, and the histological changes were in every way typical. The mildness of the inflammatory reaction may be correlated with the absence of changes in the cerebrospinal fluid, and the lesions were concentrated in the dorsal region of the thalamus and in the nuclei of the pons. The cells of the substantia nigra, which bears the greatest brunt in encephalitis lethargica, were relatively unharmed.

Two children have recently come under our care who showed a very suggestive clinical picture of this disease with mental deterioration, clumsiness of

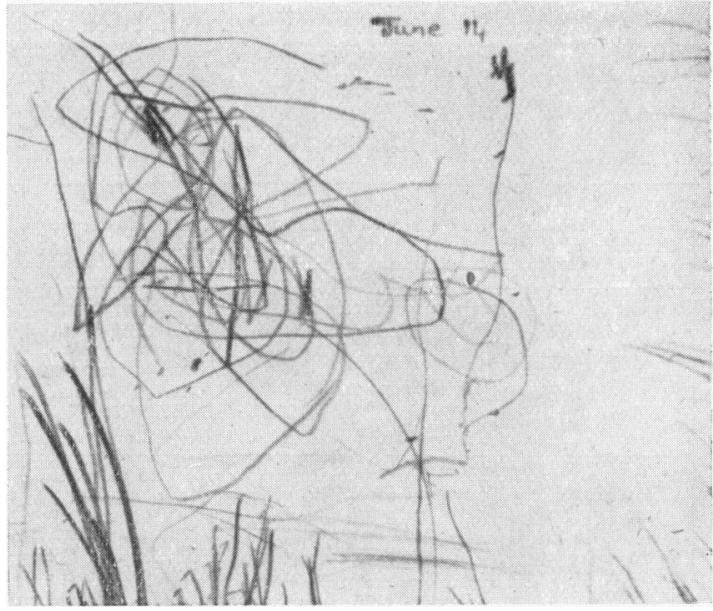

FIG. 11.-Gross deterioration in drawing on being asked to draw same subject on June 14, 1951.

movement and changes of tone in the limbs, but under observation have improved and returned to normality, and, although the electroencephalographic changes were not characteristic of this disease, the clinical picture was strikingly like sub-acute encephalitis for two to three months. We have a strong impression, which, however, cannot be proved, that certain of these cases may not end fatally and may recover and it would be interesting to know whether other observers have considered this possibility.

The electro-encephalographic recordings were interpreted as a disturbance of cerebral inhibition.

Electrical Findings. The electrical observations threw no light on the aetiology of the condition but

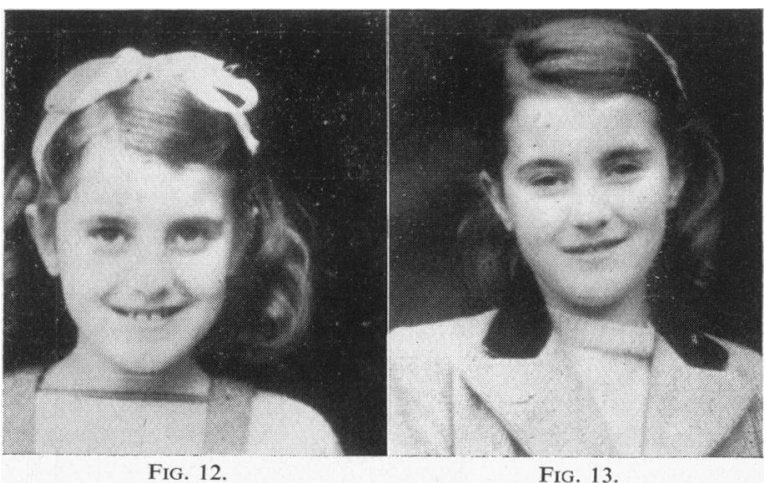

Fig. 12.-Case 1. One year before onset of symptoms. Note normal facial appearance.

Fig. 13.-Case 1. Three months after onset of earliest symptoms. Note change in facial appearance. 
TABLE 1

Principal findings in Some Cases previously Recorded

\begin{tabular}{|c|c|c|c|c|c|c|c|c|}
\hline Author & $\begin{array}{l}\text { Age } \\
\text { (in } \\
\text { years) } \\
\text { and } \\
\text { Sex }\end{array}$ & $\underset{\text { Onset }}{\text { Symptoms at }}$ & Clinical Features & Duration & C.S.F. & $\begin{array}{c}\text { Intra- } \\
\text { nuclear } \\
\text { Bodies }\end{array}$ & $\begin{array}{c}\text { Result of } \\
\text { Animal } \\
\text { Inoculation }\end{array}$ & $\begin{array}{c}\text { Further } \\
\text { Observations }\end{array}$ \\
\hline${ }_{1}^{\text {Dawson (1934) }}$ & M.16 & $\begin{array}{l}\text { Reversal of sleep } \\
\text { rhythm; abnor- } \\
\text { mal behaviour; } \\
\text { hallucinations }\end{array}$ & $\begin{array}{l}\text { Rigidity; } \\
\text { myoclonus; } \\
\text { cachexia }\end{array}$ & $\begin{array}{l}\text { Unrecorded } \\
\text { but over a } \\
\text { year }\end{array}$ & $\begin{array}{l}14 \text { cells, } \\
\text { otherwise } \\
\text { normal }\end{array}$ & Yes & Negative & $\begin{array}{l}\text { A labial herpes } \\
\text { recorded }\end{array}$ \\
\hline${ }_{2}^{\text {Dawson (1934) }}$ & F.5 & Hallucinations & $\begin{array}{l}\text { Loss of ability to } \\
\text { speak; apathy; in- } \\
\text { ability to control } \\
\text { muscles; pipe-stem } \\
\text { rigidity; pyrexia; } \\
\text { myoclonus; } \\
\text { cachexia }\end{array}$ & 4 months & Normal & Yes & Negative & $\begin{array}{l}\text { Maculo- } \\
\text { papular } \\
\text { eruption, } \\
\text { blood eosino- } \\
\text { philia }\end{array}$ \\
\hline $\begin{array}{c}\text { Van Bogaert } \\
(1945) \\
1\end{array}$ & M.3 & $\begin{array}{l}\text { Mental } \\
\text { deterioration }\end{array}$ & $\begin{array}{l}\text { Myoclonus; gradu- } \\
\text { ally increasing } \\
\text { rigidity; wasting }\end{array}$ & 3 months & Normal & No & $\begin{array}{l}\text { Not } \\
\text { performed }\end{array}$ & 一 \\
\hline $\begin{array}{c}\text { Van Bogaert } \\
(1945) \\
2\end{array}$ & M.14 & $\begin{array}{l}\text { Messy eating; } \\
\text { loss of emotions; } \\
\text { stupor; in- } \\
\text { difference to } \\
\text { surroundings }\end{array}$ & $\begin{array}{l}\text { Myoclonus; } \\
\text { tendency to bite } \\
\text { everything; aphasia; } \\
\text { apraxia; cachexia }\end{array}$ & 3 months & Normal & No & $\begin{array}{l}\text { Not } \\
\text { performed }\end{array}$ & $\begin{array}{l}\text { Allergic family } \\
\text { history; } \\
\text { measles at age } \\
\text { of } 5 \frac{1}{2}\end{array}$ \\
\hline${ }_{1}^{\text {Rosanoff (1947) }}$ & F.6 & $\begin{array}{l}\text { Lost herself in } \\
\text { streets; loss of } \\
\text { motor control; } \\
\text { tendency to fall }\end{array}$ & $\begin{array}{l}\text { Tended to bite } \\
\text { everything; in- } \\
\text { creased tone in the } \\
\text { legs; no myoclonus; } \\
\text { cachexia }\end{array}$ & 9 months & Normal & No & $\begin{array}{l}\text { Not } \\
\text { performed }\end{array}$ & 一 \\
\hline $\operatorname{Rosanoff}_{2}(1947)$ & М.9 & $\begin{array}{l}\text { Lapses of } \\
\text { consciousness; } \\
\text { falling to the } \\
\text { floor, unable to } \\
\text { carry out errands }\end{array}$ & $\begin{array}{l}\text { Meaningless facies; } \\
\text { right extensor } \\
\text { plantar; apraxia; } \\
\text { cachexia, no } \\
\text { myoclonus }\end{array}$ & 4 months. & $\begin{array}{l}\text { Paretic } \\
\text { Lange curve }\end{array}$ & No & $\begin{array}{l}\text { Not } \\
\text { performed }\end{array}$ & - \\
\hline $\begin{array}{l}\text { Malamud, } \\
\text { Haymaker and } \\
\text { Pinkerton (1950) } \\
1\end{array}$ & M.17 & $\begin{array}{l}\text { Psychosis; } \\
\text { apathy; } \\
\text { disorientation }\end{array}$ & $\begin{array}{l}\text { Ptosis on the left; } \\
\text { pill-rolling tremor; } \\
\text { cachexia; } \\
\text { emaciation }\end{array}$ & 9 months & $\begin{array}{l}\text { Paretic } \\
\text { Lange curve }\end{array}$ & Yes & $\begin{array}{l}\text { Not } \\
\text { performed }\end{array}$ & 一 \\
\hline $\begin{array}{c}\text { Malamud et al. } \\
(1950) \\
2\end{array}$ & F.9 & $\begin{array}{l}\text { Irritable; } \\
\text { deterioration in } \\
\text { school work; } \\
\text { frequent falls }\end{array}$ & $\begin{array}{l}\text { Optic atrophy; } \\
\text { opisthotonos; } \\
\text { apathy; myoclonus; } \\
\text { wasting }\end{array}$ & 21 months & Normal & Yes & $\begin{array}{l}\text { Not } \\
\text { performed }\end{array}$ & 一 \\
\hline $\begin{array}{c}\text { Malamud } e t ~ a l . \\
(1950) \\
3\end{array}$ & F.10 & $\begin{array}{l}\text { Gradual } \\
\text { intellectual } \\
\text { impairment }\end{array}$ & $\begin{array}{l}\text { Progressive blind- } \\
\text { ness; myoclonus; } \\
\text { wasting }\end{array}$ & 7 years & Not recorded & Yes & $\begin{array}{l}\text { Not } \\
\text { performed }\end{array}$ & $\begin{array}{l}\text { Degenerative } \\
\text { lesion at the } \\
\text { macula of the } \\
\text { eye }\end{array}$ \\
\hline $\begin{array}{l}\text { Brain, } \\
\text { Greenfield and } \\
\text { Russell (1948) } \\
\qquad 1\end{array}$ & M.4 & $\begin{array}{l}\text { Limping; loss of } \\
\text { use of right leg; } \\
\text { faecal inconti- } \\
\text { nence }\end{array}$ & $\begin{array}{l}\text { Indistinct speech; } \\
\text { blindness; inability } \\
\text { to sit up; no } \\
\text { myoclonus }\end{array}$ & 11 weeks & Normal & Yes & $\begin{array}{l}\text { Not } \\
\text { performed }\end{array}$ & 一 \\
\hline $\begin{array}{c}\text { Brain et al. } \\
(1948) \\
2\end{array}$ & M.11 & $\begin{array}{l}\text { Forgetfulness on } \\
\text { errands; messy } \\
\text { eater; unsteadi- } \\
\text { ness of gait; in- } \\
\text { continent of } \\
\text { urine }\end{array}$ & $\begin{array}{l}\text { Slow of speech; } \\
\text { left facial weakness; } \\
\text { myoclonus; wasting }\end{array}$ & 3 months & Normal & Yes & Negative & $\begin{array}{l}\text { Inoculated } \\
\text { against } \\
\text { diphtheria }\end{array}$ \\
\hline $\begin{array}{c}\text { Brain et al. } \\
\text { (1948) } \\
3\end{array}$ & F.10 & $\begin{array}{l}\text { Work became } \\
\text { slovenly; unable } \\
\text { to dress herself; } \\
\text { speech } \\
\text { unintelligible }\end{array}$ & $\begin{array}{l}\text { Increased tone; } \\
\text { myoclonus }\end{array}$ & 9 weeks & $\begin{array}{l}\text { Paretic } \\
\text { Lange curve }\end{array}$ & Yes & Negative & Had measles \\
\hline
\end{tabular}

they did permit inference of the likely extent of the lesions. The cerebral cortex, in Case 1, though deeply involved in the discharges, seemed unlikely to be directly responsible for the spasmodic outbursts; its role was rather to modify and perhaps to relay the pathological discharges from deep-lying structures.

The electrical features resembled superficially those seen in certain forms of myoclonic epilepsy, but there are two differences which may turn out to be useful in distinguishing this from the other conditions; the muscle groups involved in this case were mainly-at any rate at this stage of the disease - the extensors, and the electromyograms always changed an appreciable time after the start of the cerebral discharge. This interval between the 


\begin{tabular}{|c|c|c|c|c|c|c|c|c|}
\hline Author & $\begin{array}{l}\text { Age } \\
\text { (in } \\
\text { years) } \\
\text { and } \\
\text { Sex }\end{array}$ & $\begin{array}{c}\text { Symptoms at } \\
\text { Onset }\end{array}$ & Clinical Features & Duration & C.S.F. & $\begin{array}{l}\text { Intra- } \\
\text { nuclear } \\
\text { Bodies }\end{array}$ & $\begin{array}{c}\text { Result of } \\
\text { Animal } \\
\text { Inoculation }\end{array}$ & $\begin{array}{c}\text { Further } \\
\text { Observations }\end{array}$ \\
\hline $\begin{array}{c}\text { Brain et al. } \\
\text { (1948) } \\
4\end{array}$ & M.5 & $\begin{array}{l}\text { Stumbling and } \\
\text { dropping things; } \\
\text { tendency to fall; } \\
\text { apathy }\end{array}$ & $\begin{array}{l}\text { Right facial paraly- } \\
\text { sis; progressive } \\
\text { cerebral deteriora- } \\
\text { tion; myoclonus }\end{array}$ & 3 months & $\begin{array}{l}\text { No Lange } \\
\text { curve done, } \\
\text { otherwise } \\
\text { normal }\end{array}$ & Yes & $\begin{array}{l}\text { Not } \\
\text { performed }\end{array}$ & 一 \\
\hline $\begin{array}{l}\text { Akelait is and } \\
\text { Zeldis (1942) }\end{array}$ & M.5 & $\begin{array}{l}\text { Sudden onset; } \\
\text { spastic arm; } \\
\text { stupor }\end{array}$ & $\begin{array}{l}\text { Dysarthria, torsion } \\
\text { spasm; ocular para- } \\
\text { lysis; myoclonus }\end{array}$ & 9 weeks & $\begin{array}{l}\text { Paretic } \\
\text { Lange curve }\end{array}$ & Yes & $\begin{array}{l}\text { Not } \\
\text { performed }\end{array}$ & - \\
\hline $\begin{array}{c}\text { Greenfield } \\
(1950) \\
1\end{array}$ & M.9 & Dropping things & $\begin{array}{l}\text { Myoclonus; bila- } \\
\text { teral facial weak- } \\
\text { ness; rigidity of } \\
\text { muscles; } \\
\text { opisthotonus }\end{array}$ & 5 months & $\begin{array}{l}\text { Paretic } \\
\text { Lange curve; } \\
\text { raised } \\
\text { pressure }\end{array}$ & Yes & $\begin{array}{l}\text { Not } \\
\text { performed }\end{array}$ & $\begin{array}{l}\text { Rubella and } \\
\text { cerebrospinal } \\
\text { fever }\end{array}$ \\
\hline $\begin{array}{r}\text { Greenfield } \\
(1950) \\
2\end{array}$ & F.9 & $\begin{array}{l}\text { Incontinence of } \\
\text { urine; falling } \\
\text { about; apathy; } \\
\text { inability to carry } \\
\text { out errands }\end{array}$ & $\begin{array}{l}\text { Meaningless smile; } \\
\text { myoclonus; in- } \\
\text { creasing rigidity; } \\
\text { opisthotonus }\end{array}$ & $4 \frac{1}{2}$ months & $\begin{array}{l}\text { Paretic } \\
\text { Lange curve, } \\
\text { otherwise } \\
\text { normal }\end{array}$ & Yes & $\begin{array}{l}\text { Not } \\
\text { performed }\end{array}$ & - \\
\hline $\begin{array}{r}\text { Greenfield } \\
(1950) \\
3\end{array}$ & F.11 & $\begin{array}{l}\text { Deterioration in } \\
\text { school work; } \\
\text { awkwardness in } \\
\text { movement; } \\
\text { becoming blind; } \\
\text { tendency to drop } \\
\text { things; lack of } \\
\text { voluntary speech }\end{array}$ & Increasing coma & $7 \frac{1}{2}$ months & $\begin{array}{l}\text { Paretic } \\
\text { Lange curve } \\
\text { otherwise } \\
\text { normal }\end{array}$ & Yes & $\begin{array}{l}\text { Not } \\
\text { performed }\end{array}$ & . \\
\hline $\begin{array}{r}\text { Greenfield } \\
\text { (1950) }\end{array}$ & F.20 & $\begin{array}{l}\text { Inability to walk; } \\
\text { lack of facial } \\
\text { expression; } \\
\text { incontinence }\end{array}$ & $\begin{array}{l}\text { Total paralysis of all } \\
\text { four limbs with gross } \\
\text { rigidity; } \\
\text { Parkinsonism }\end{array}$ & 6 months & $\begin{array}{l}\text { Paretic } \\
\text { Lange curve }\end{array}$ & No & $\begin{array}{l}\text { Not } \\
\text { performed }\end{array}$ & $\begin{array}{l}\text { At age of } 17 \text {, } \\
\text { vulvar warts }\end{array}$ \\
\hline Corsellis (1951) & F. $18 \frac{1}{2}$ & $\begin{array}{l}\text { Stumbling about; } \\
\text { vacant; unable } \\
\text { to dress or feed } \\
\text { herself }\end{array}$ & $\begin{array}{l}\text { Developed myo- } \\
\text { clonic attacks; extra } \\
\text { pyramidal rigidity; } \\
\text { bilateral ptosis }\end{array}$ & 6 months & $\begin{array}{l}\text { Paretic } \\
\text { Lange curve; } \\
\text { slightly raised } \\
\text { protein }\end{array}$ & No & $\begin{array}{l}\text { Not } \\
\text { performed }\end{array}$ & $\begin{array}{l}\text { Was unsteady } \\
\text { on her feet at } \\
\text { age of } 3 \text { and } \\
\text { suffered from a } \\
\text { febrile illness } \\
\text { at } 17 \frac{1}{8}\end{array}$ \\
\hline Corsellis (1951) & F.20 & $\begin{array}{l}\text { Unsteadiness of } \\
\text { legs; dementia; } \\
\text { tended to fall } \\
\text { over }\end{array}$ & $\begin{array}{l}\text { Irregular pyrexia; } \\
\text { stuporose; spastic- } \\
\text { ity of left arm and } \\
\text { right leg }\end{array}$ & $\begin{array}{l}\text { Uncertain, } \\
\text { possibly a } \\
\text { year or } \\
\text { more }\end{array}$ & $\begin{array}{l}\text { Paretic } \\
\text { Lange curve; } \\
\text { protein raised }\end{array}$ & No & $\begin{array}{l}\text { Not } \\
\text { performed }\end{array}$ & $\begin{array}{l}\text { This patient } \\
\text { has always } \\
\text { been of a low } \\
\text { grade mentality }\end{array}$ \\
\hline $\begin{array}{l}\text { Martin, } \\
\text { Macken and } \\
\text { Hess (1950) }\end{array}$ & M.7 & $\begin{array}{l}\text { Alteration in } \\
\text { personality; } \\
\text { apathy; work } \\
\text { deterioration }\end{array}$ & $\begin{array}{l}\text { Myoclonic move- } \\
\text { ments; fixed facial } \\
\text { expression }\end{array}$ & 6 months & $\begin{array}{l}\text { Paretic } \\
\text { Lange curve }\end{array}$ & Yes & $\begin{array}{l}\text { Still under in- } \\
\text { vestigation. } \\
\text { Cerebral signs } \\
\text { in rabbits, } \\
\text { possibly } \\
\text { encephalitis }\end{array}$ & $\begin{array}{l}\text { Whooping } \\
\text { cough only in } \\
\text { previous } \\
\text { history }\end{array}$ \\
\hline $\begin{array}{l}\text { Clearkih and } \\
\text { Millar (1952) }\end{array}$ & 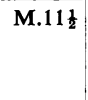 & $\begin{array}{l}\text { Transient losses } \\
\text { of consciousness; } \\
\text { deterioration in } \\
\text { school work }\end{array}$ & $\begin{array}{l}\text { Myoclonic move- } \\
\text { ments; Parkinson- } \\
\text { ian features; finally } \\
\text { deaf and blind }\end{array}$ & 4 months & $\begin{array}{l}\text { Paretic } \\
\text { Lange curve }\end{array}$ & No & $\begin{array}{l}\text { Not } \\
\text { performed }\end{array}$ & - \\
\hline $\begin{array}{r}\text { Our Case } \\
1\end{array}$ & F.11 & $\begin{array}{l}\text { Personality } \\
\text { changes; unable } \\
\text { to perform } \\
\text { errands; went to } \\
\text { bed with boots } \\
\text { on; falling down }\end{array}$ & $\begin{array}{l}\text { Myoclonic move- } \\
\text { ments; left facial } \\
\text { weakness }\end{array}$ & 6-9 months & Normal & Yes & Negative & $\begin{array}{l}\text { Severe onset } \\
\text { three months } \\
\text { before symp- } \\
\text { toms }\end{array}$ \\
\hline $\begin{array}{r}\text { Our Case } \\
2\end{array}$ & F.6 & $\begin{array}{l}\text { Deterioration in } \\
\text { school work; } \\
\text { tendency to fall } \\
\text { down }\end{array}$ & $\begin{array}{l}\text { Myoclonic move- } \\
\text { ments; opisthotonic } \\
\text { rigidity }\end{array}$ & 2-3 months & $\begin{array}{l}\text { Paretic } \\
\text { Lange curve }\end{array}$ & Yes & Negative & $\begin{array}{l}\text { Infantile } \\
\text { convulsions }\end{array}$ \\
\hline
\end{tabular}

central and peripheral events was never less and often more than $0 \cdot 1$ seconds, suggesting that the discharge to the periphery may have been relayed through the cortical motor zone.

In myoclonus epilepsy, on the other hand, there is usually a predominance of flexor jerks giving rise to the complaint of falling or weakness, and there 
in this case, however, it seems more likely that the subcortical involvement was at least one stage further from the centrifugal channels.

Another question raised by these studies is whether the intimate nature of the lesion responsible for the discharge was excitatory or inhibitory. The amplitude and regularity of the electrical phenomena may at first sight suggest a frankly irritative or excitatory process, but there are several features which indicate greater complexity. In the first place, the largest cerebral component, the sharp wave, was not particularly brief or restricted; its duration was about 0.2 seconds and it could not be considered as a spike. This, together with the very extensive slow wave, the grouping of the muscle discharges and the invariable 'silent period' after the second discharge in the muscles, suggest that the pathological process may have been in the nature of an alternation between 'inhibition of inhibition' or 'depression of suppression' and inhibitory rebound. Such a process of release from control is also somewhat easier to fit in with the unusual regularity of the repetition rate and wave-form of the cerebral paroxysms.

\section{Summary}

Two cases of sub-acute encephalitis are recorded and contrasted with previous cases.
Pathological and electro-encephalographic records are discussed, and it is pointed out that the different pathological changes may be due to the very great difference in the length of the symptoms in the two cases.

It is suggested that this disease is commoner than has been imagined and every effort should be made to throw some light on its aetiology.

We are much indebted to Professor A. V. Neale for the clinical material. We also acknowledge with gratitude the assistance of Professor Hewer, Dr. Greenfield, Dr. Brown and Dr. Dodgson. For the virus studies we are indebted to Dr. E. Weston Hurst, of Imperial Chemical Industries Ltd., and for the photographs to the photographic staff of Bristol University.

REFERENCES

Akelaitis, A. J. and Zeldis, L. J. (1942). Arch. Neurol. Psychiat., Chicago, 47, 353.

Brain, W. R., Greenfield, J. G. and Russell, D. S. (1948). Brain, 71, i 365 .

Clearkin, K. B. and Millar, J. H. D. (1952). Electroenceph. clin. Neurophysiol. 4,105 .

Corsellis, J. A. N. (1951). J. ment. Sci., 97, 570.

Dawson, J. R. (1934). Arch. Neurol. Psychiat., Chicago, 31, 685.

Greenfield, J. G. (1950). Brain, 73, 141.

Malamud, N., Haymaker, W. and Pinkerton, H. (1950). Amer. J. Path., 26, 133.

Martin, F., Macken, J. and Hess, R. (1950). Schweiz. Arch. Neurol. Psychiat., 66, 217.

Rosanoff, W. R. (1947). J. Neurol. Neurosurg. Psychiat., 10, 61. Van Bogaert, L. (1945). Ibid., 8, 101. 
Die Zerebrale Angiographie. By H. KRAYENBütH and H. R. Richter. (Pp. VIII + 213; 100 illustrations. D.M. 597.) Stuttgart: Georg Thieme. 1952.

One has no hesitation in commending this book to all interested in the central nervous system. It is fully illustrated with excellent reproductions of cerebral arteriograms, nearly all accompanied by line drawings with the principal vessels identified and the abnormalities clearly indicated.

A quick perusal of the illustrations would soon convince one of the value of cerebral angiography as a diagnostic procedure. In the years that have passed since Moniz performed the first carotid arteriogram (1927) many of the possibilities of the examination have been realized, as this volume shows. In particular much of the authors' recent work on the normal and pathological anatomy of the deep cerebral veins is included. It used to be believed that cerebral angiography was of no value in the localization of central tumours when pathological vessels were not demonstrable. However, now that the radiological anatomy of the deep veins has been described, it is possible to localize these tumours by the manner in which they dislocate veins even when the cerebral arteriogram is substantially normal. It is not reasonable, however, to expect more accuracy than is obtained by pneumography.
As a neuroradiologist I would like to have seen more of the lateral arteriograms accompanied by antero-posterior projections, but this could only have been done at the cost of reducing the number of cases reported.

The bibliography is comprehensive.

Residential Speech Therapy. Edited by C. WorsTerDroughr. (Pp. 150; illustrated. 15s.) London: Wm. Heinemann Medical Books Ltd. 1952.

Some children with defective speech, due to a variety of causes, need more observation and treatment than can be provided in one or two weekly attendances at an outpatient clinic. Moor House School was opened in 1947 for such patients, and this book is an account of its first two years' work and of the first 36 children who were accepted as residents. It is often difficult for outsiders to know what goes on in new and specialized institutions, hence the value of this account. It is truly original, for it describes what was observed without attempting any detailed survey of the work of others in the field of speech therapy, and those who have to deal with serious cases of this type will find the book interesting and useful. The literary style is clear, technical and unadorned: there are illustrations, tables, appendices and an index.

\section{Corrections}

The Editors regret that in the title of the paper by A. M. G. Campbell, Joan Guy and W. Grey Walter published in the December, 1952, issue of the Archives of Disease in Childhood $(27,507)$, the word "cytomegalic" was inserted. The correct title should be " Two Cases of Inclusion Encephalitis".

In the paper "Vomiting of Uncertain Origin in Young Infants," Archives of Disease in Childhood, 27,
562, the legend to Fig. 1 should read : "Comparison of average growth curves in persistent and non-persistent vomiting of uncertain origin."

The vertical lines (Max.) indicate the maximum deviation from the normal weight, which occurs at very different ages in the two groups.

The first four words of line 15 , column 2, page 563 should be deleted. 